\title{
Ocena wiedzy kobiet na temat seksualnych czynników ryzyka raka szyjki macicy*
}

\section{Assessment of knowledge of women regarding sexual risk factors for cervical cancer}

\author{
Magdalena Sulima', Magdalena Lewicka', Krzysztof Wiktor², Grzegorz Bakalczuk¹, Henryk Wiktor ${ }^{1}$ \\ ${ }^{1}$ Zakład Położnictwa, Ginekologii i Pielęgniarstwa Położniczo-Ginekologicznego Uniwersytetu Medycznego w Lublinie \\ ul. Chodźki 6, 20-093 Lublin \\ Kierownik: prof. dr hab. n. med. Henryk Wiktor
}

2 Katedra i Klinika Ginekologii i Endokrynologii Ginekologicznej Uniwersytetu Medycznego w Lublinie

Aleje Racławickie 23, 20-037 Lublin

Kierownik: prof. dr hab. n. med. Lechosław Putowski

\begin{abstract}
Introduction: In Poland, reproductive system cancers are an important medical and social problem. Risky sexual behaviours such as early age of sexual initiation, or a large number of sexual partners increase the risk of cervical cancer.

The aim of this study was to assess the knowledge of women about sexual risk factors for cervical cancer.

Materials and methods: The study included 200 women from the cities of Lublin and Radom, and the village of Jabłonna. Respondents completed a diagnostic survey questionnaire specially developed for the purpose of this study. The results were statistically analysed.

Results: A statistically significant relationship was found between the knowledge of respondents about early start of sexual intercourse as a risk factor for cervical cancer and their
\end{abstract}

marital status $(\mathrm{p}=0.003)$, place of residence $(\mathrm{p}=0.01)$ and type of professional activity $(p=0.03)$. There was also a statistically significant relationship between the knowledge of the surveyed women on a large number of sexual partners as a risk factor for cervical cancer and age $(p=0.002)$, marital status $(p=0.03)$, and the type of professional activity.

Conclusions: Women know that the early age of sexual initiation and a large number of sexual partners is a risk factor for cervical cancer. On the other hand, they are not aware of the impact of a large number of sexual partners of their current partner on the risk of cervical cancer. There is a need to educate women about the impact of risky sexual behaviour on the potential development of cervical cancer.

Keywords: cancer, sexual intercourse, sexual partner.

\section{STRESZCZENIE}

Wstęp: W Polsce nowotwory narządu rodnego są istotnym problemem medycznym, jak również społecznym. Ryzykowne zachowania seksualne, takie jak: wczesne rozpoczęcie współżycia seksualnego, duża liczba partnerów seksualnych oraz duża liczba partnerek seksualnych obecnego partnera, zwiększają prawdopodobieństwo wystąpienia nowotworu szyjki macicy. Celem pracy była ocena wiedzy kobiet na temat seksualnych czynników ryzyka raka szyjki macicy.

Materiał i metoda: Badaniami objęto 200 kobiet pochodzących z Lublina i Radomia oraz wsi Jabłonna. Badania przeprowadzono metodą sondażu diagnostycznego z zastosowaniem kwestionariusza ankiety własnego autorstwa opracowanego dla potrzeb niniejszej pracy. Uzyskane wyniki badań poddano analizie statystycznej.

Wyniki: Stwierdzono istotną statystycznie zależność pomiędzy wiedzą badanych kobiet na temat wczesnego rozpoczęcia współżycia seksualnego jako czynnika ryzyka raka szyjki macicy a stanem cywilnym $(p=0,003)$, miejscem zamieszkania $(p=0,01)$ oraz formą aktywności zawodowej $(p=0,03)$. Ponadto stwierdzono istotną statystycznie zależność pomiędzy wiedzą badanych kobiet na temat dużej liczby partnerów seksualnych jako czynnika ryzyka raka szyjki macicy a wiekiem $(p=0,002)$, stanem cywilnym $(p=0,03)$ oraz formą aktywności zawodowej. Wnioski: Kobiety wiedzą, że wczesne rozpoczęcie współżycia seksualnego oraz duża liczba partnerów seksualnych to czynniki ryzyka nowotworu szyjki macicy. Natomiast nie posiadają wiedzy o wpływie dużej liczby partnerek seksualnych obecnego partnera na możliwość wystąpienia nowotworu szyjki macicy. Istnieje potrzeba prowadzenia działań edukacyjnych wśród kobiet na temat wpływu ryzykownych zachowań seksualnych na możliwości rozwoju raka szyjki macicy.

Słowa kluczowe: nowotwór, współżycie seksualne, partner seksualny.

\footnotetext{
* Artykuł napisany na podstawie pracy magisterskiej Magdaleny Bąk (obecnie Magdalena Sulima) pt. „Ocena stanu wiedzy kobiet w zakresie czynników ryzyka raka szyjki macicy” obronionej na Wydziale Pielęgniarstwa i Nauk o Zdrowiu Akademii Medycznej w Lublinie. Promotor: prof. dr hab. n. med. Henryk Wiktor. Oryginał zawiera:
} 296 stron, 97 tabel oraz 195 pozycji piśmiennictwa. 
W Polsce nowotwory narządu rodnego są istotnym problemem medycznym, jak również społecznym. Rak szyjki macicy jest drugim co do częstości, po raku piersi, nowotworem złośliwym wśród kobiet [1,2,3]. Literatura przedmiotu podaje, że z powodu raka szyjki macicy umiera dziennie 5 polskich kobiet. Polska należy do krajów, w którym współczynniki zachorowalności i umieralności są jednymi z najwyższych w Europie, czego główną przyczyną jest późne rozpoznawanie tego schorzenia, jak również mała zgłaszalność kobiet na okresowe badania do lekarza ginekologa [4, 5].

Ryzykowne zachowania seksualne, takie jak: wczesne rozpoczęcie współżycia seksualnego, duża liczba partnerów seksualnych oraz duża liczba partnerek seksualnych obecnego partnera, zwiększają prawdopodobieństwo wystąpienia nowotworu szyjki macicy. Wiedza na temat seksualnych czynników ryzyka raka szyjki macicy oraz regularnie przeprowadzane badania profilaktyczne są jednymi z najważniejszych czynników zmniejszających ryzyko rozwoju tego nowotworu $[6,7,8]$.

Celem pracy była ocena wiedzy kobiet na temat seksualnych czynników ryzyka raka szyjki macicy.

\section{MATERIA I I METODY}

Badaniami objęto 200 kobiet pochodzących z Lublina i Radomia oraz wsi Jabłonna. Badania przeprowadzono metodą sondażu diagnostycznego z zastosowaniem kwestionariusza ankiety własnego autorstwa opracowanego dla potrzeb niniejszej pracy. Udział w badaniach był dobrowolny i anonimowy. Uzyskane wyniki poddano analizie statystycznej. Przyjęto $5 \%$ ryzyko błędu wnioskowania; $p<0,05$ uznano za istotne statystycznie.

Wiek badanych wahał się w granicach 20-66 lat; 92 kobiety $(46,0 \%)$ były w wieku 20-30 lat, $22(11,0 \%)$ w wieku 31-40 lat, 57 (28,50\%) w wieku 41-50 lat, zaś 21 (10,50\%) w wieku 51-60 lat oraz $8(4,0 \%)$ powyżej 6o. r.ż.

W objętej badaniami grupie kobiet 108 (54,0\%) posiadało wykształcenie wyższe, 65 (32,50\%) średnie, 19 (9,50\%) zasadnicze zawodowe, natomiast $8(4,0 \%)$ wykształcenie podstawowe.

Mieszkankami miasta wojewódzkiego były 53 (26,50\%) badane, $94(47,0 \%)$ miasta powiatowego, zaś 53 (26,50\%) były mieszkankami wsi. Wśród kobiet były 92 (46\%) mężatki, $82(41,0 \%)$ panny, $18(9,0 \%)$ rozwódek oraz 8 (4,0\%) wdów. Zawodowo pracowało 97 (48,50\%) badanych, 14 (7,0\%) było bezrobotnych, $24(12,0 \%)$ były emerytkami lub rencistkami, natomiast $65(32,50 \%)$ studentkami.

\section{WYNIKI}

W tabeli 1 przedstawiono współzależność pomiędzy wiedzą badanych kobiet na temat wczesnego rozpoczęcia współżycia seksualnego jako czynnika zwiększającego ryzyko powstania raka szyjki macicy a czynnikami socjodemograficznymi.
Największy odsetek badanych, które wiedziały, że wczesne rozpoczęcie współżycia seksualnego jest czynnikiem ryzyka raka szyjki macicy, stanowiły kobiety w wieku 20-30 lat ( $\mathrm{n}=51,55,44 \%)$, rozwódki $(\mathrm{n}=14,77,78 \%)$, legitymujące się wykształceniem zawodowym ( $\mathrm{n}=12,63,16 \%)$, mieszkanki miasta wojewódzkiego ( $\mathrm{n}=36,67,93 \%$ ), będące studentkami ( $n=45,69,24 \%$ ). Natomiast największy odsetek badanych kobiet, które nie wiedziały, że wczesne rozpoczęcie współżycia seksualnego jest czynnikiem ryzyka tego nowotworu, stanowiły kobiety w wieku powyżej 60 lat ( $\mathrm{n}=3,37,50 \%)$, wdowy $(\mathrm{n}=4,50,00 \%)$, kobiety z wykształceniem podstawowym $(\mathrm{n}=4$, $50,00 \%)$, emerytki/rencistki $(\mathrm{n}=10,41,67 \%)$, zamieszkujące wieś ( $\mathrm{n}=21,39,62 \%)$.

Stwierdzono istotną statystycznie zależność pomiędzy wiedzą badanych kobiet na temat wczesnego rozpoczęcia współżycia seksualnego jako czynnika ryzyka raka szyjki macicy a stanem cywilnym $(p=0,003)$, miejscem zamieszkania $(p=0,01)$ oraz formą aktywności zawodowej $(p=0,03)$. Nie stwierdzono natomiast statystycznie istotnej zależności pomiędzy wiedzą badanych kobiet na temat wczesnego rozpoczęcia współżycia seksualnego jako czynnika ryzyka raka szyjki macicy a wiekiem $(p=0,15)$ oraz wykształceniem $(p=0,29)$.

W tabeli 2 przedstawiono współzależność pomiędzy wiedzą badanych kobiet na temat dużej liczby partnerów seksualnych jako czynnika zwiększającego ryzyko powstania raka szyjki macicy a czynnikami socjodemograficznymi.

Największy odsetek badanych, które wiedziały, że duża liczba partnerów seksualnych jest czynnikiem ryzyka raka szyjki macicy, stanowiły kobiety w wieku 20-30 lat ( $\mathrm{n}=67,72,83 \%)$, panny $(\mathrm{n}=62,75,61 \%)$, posiadające wykształcenie zawodowe ( $n=15,78,95 \%)$, mieszkanki miasta wojewódzkiego ( $n=39$, $73,58 \%)$, jak i wsi $(n=39,73,58 \%)$, a także bezrobotne $(n=11$, 78,57\%). Z kolei największy odsetek kobiet, które nie wiedziały, że duża liczba partnerów seksualnych jest czynnikiem zwiększającym ryzyko raka szyjki macicy, stanowiły kobiety w wieku powyżej 60 lat ( $n=6,75,00 \%)$, legitymujące się wykształceniem podstawowym $(\mathrm{n}=4,50,00 \%)$, emerytki/rencistki $(\mathrm{n}=10$, $41,67 \%)$, mieszkanki miasta powiatowego ( $n=24,25,53 \%)$.

Stwierdzono istotną statystycznie zależność pomiędzy wiedzą badanych kobiet na temat dużej liczby partnerów seksualnych jako czynnika ryzyka raka szyjki macicy a wiekiem $(p=0,002)$, stanem cywilnym $(p=0,03)$ oraz formą aktywności zawodowej $(p=0,006)$. Nie stwierdzono natomiast statystycznie istotnej zależności pomiędzy wiedzą badanych kobiet na temat dużej liczby partnerów seksualnych jako czynnika ryzyka nowotworu szyjki macicy a wykształceniem $(p=0,11)$ oraz miejscem zamieszkania $(p=0,51)$.

W tabeli 3 przedstawiono współzależność pomiędzy wiedzą badanych kobiet na temat dużej liczby partnerek seksualnych obecnego partnera seksualnego jako czynnika zwiększającego ryzyko powstania raka szyjki macicy a czynnikami socjodemograficznymi.

Największy odsetek badanych kobiet, które wiedziały, że duża liczba partnerek seksualnych obecnego partnera seksualnego jest czynnikiem zwiększającym ryzyko raka szyjki macicy, stanowiły kobiety w wieku 51-60 lat ( $\mathrm{n}=39,66 \%$ ), 
TABELA 1. Współzależność pomiędzy wiedzą badanych kobiet na temat wczesnego rozpoczęcia współżycia seksualnego jako czynnika zwiększającego ryzyko powstania raka szyjki macicy a czynnikami socjodemograficznymi

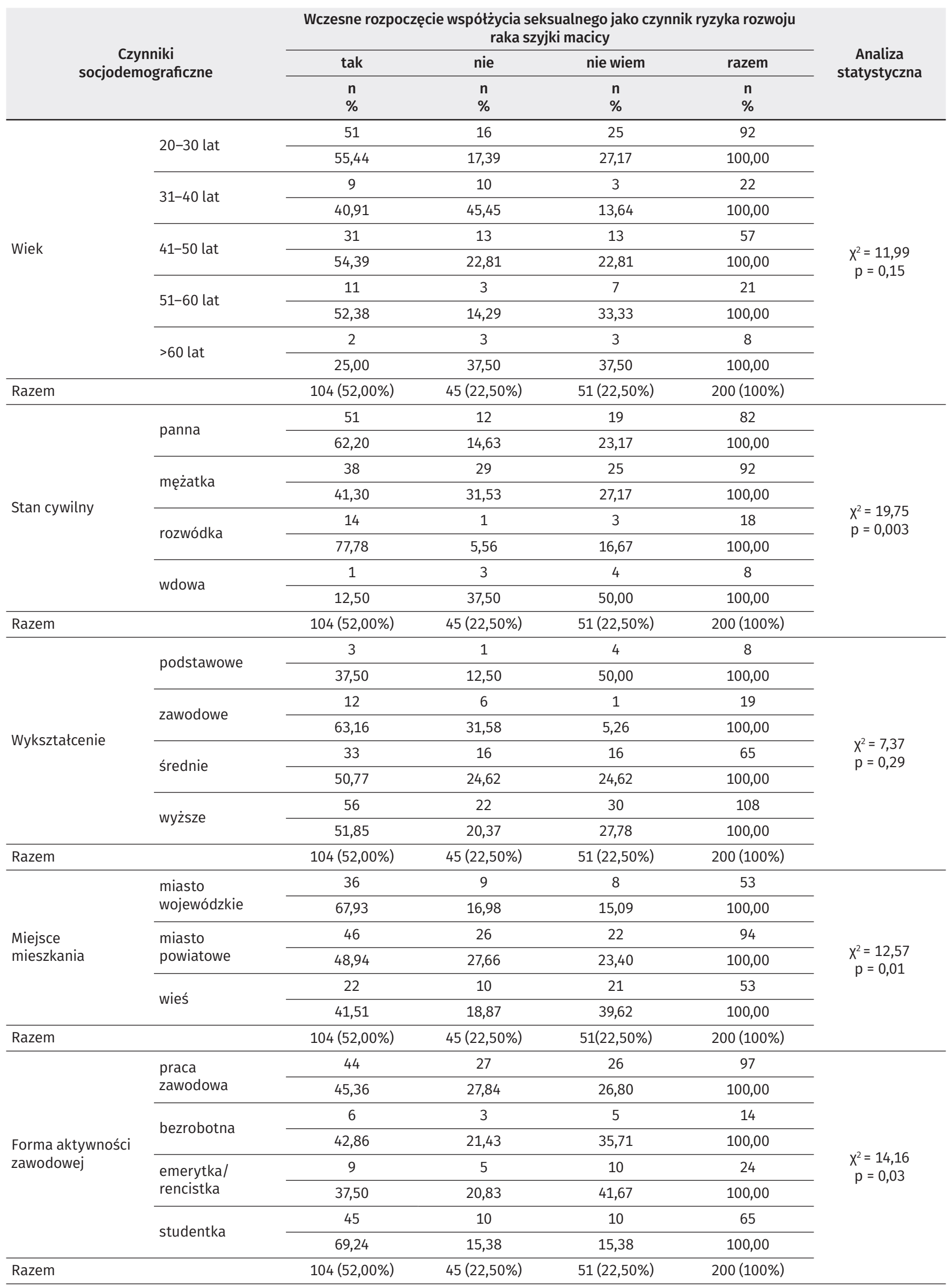


TABELA 2. Współzależność pomiędzy wiedzą badanych kobiet na temat dużej liczby partnerów seksualnych jako czynnika zwiększającego ryzyko powstania raka szyjki macicy a czynnikami socjodemograficznymi

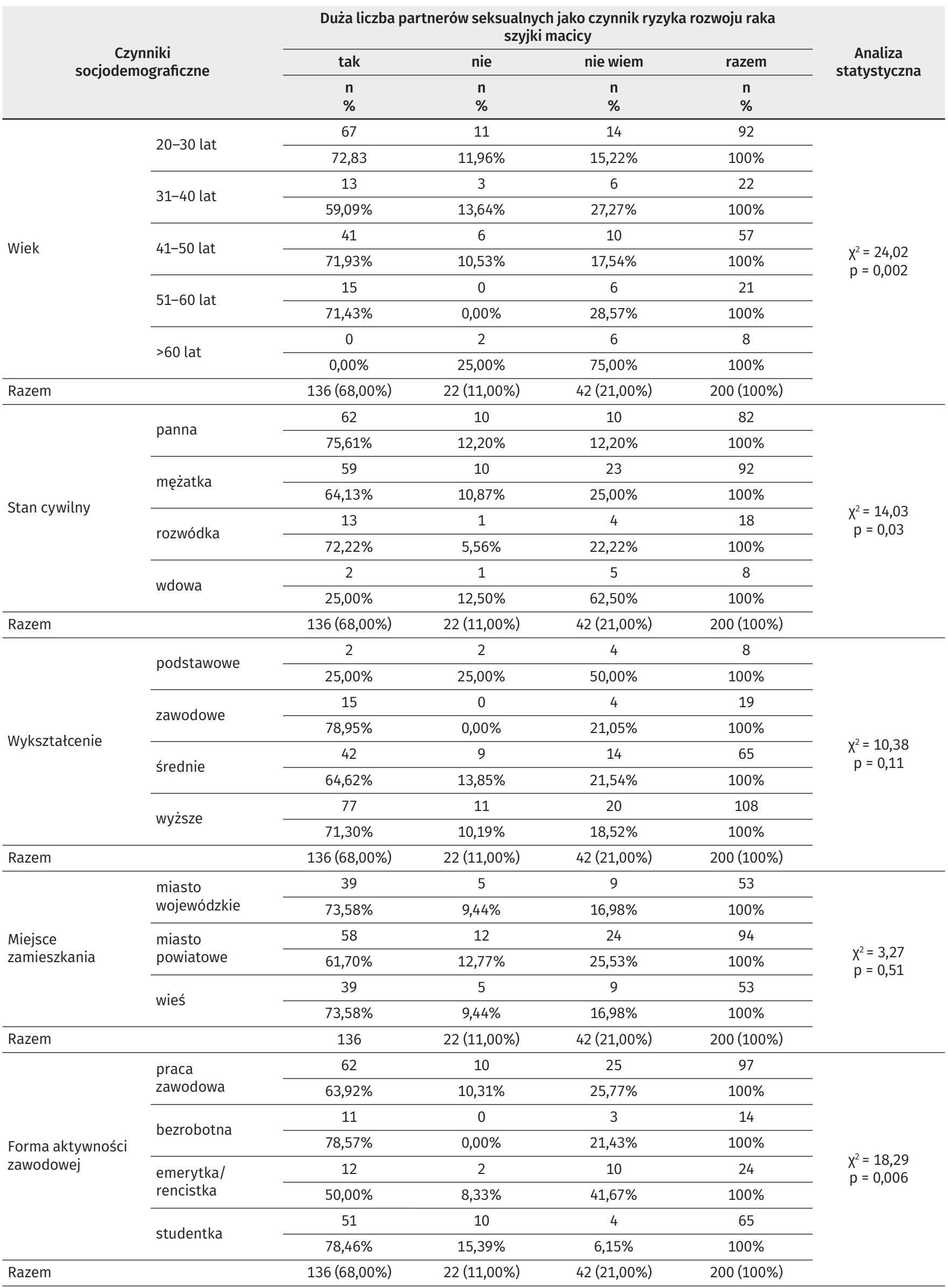


TABELA 3. Współzależność pomiędzy wiedzą badanych kobiet na temat dużej liczby partnerek seksualnych obecnego partnera seksualnego jako czynnika zwiększającego ryzyko powstania raka szyjki macicy a czynnikami socjodemograficznymi

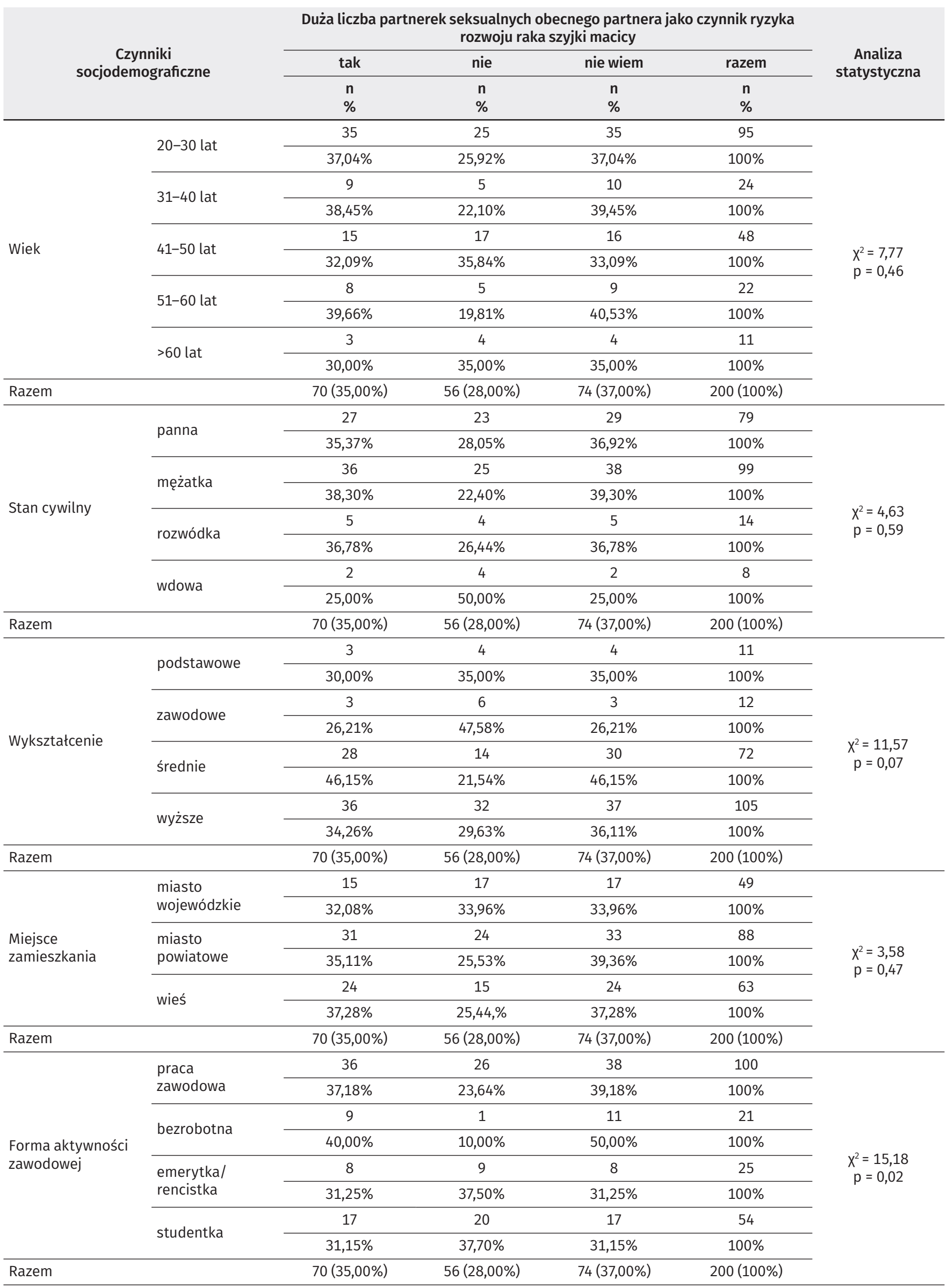


legitymujące się wykształceniem średnim $(\mathrm{n}=28,46,15 \%)$, zamieszkujące wieś ( $\mathrm{n}=24,37,28 \%)$, niepracujące $(\mathrm{n}=9$, 40,00\%). Z kolei największy odsetek kobiet, które nie wiedziały, że duża liczba partnerek seksualnych obecnego partnera seksualnego jest czynnikiem zwiększającym ryzyko raka szyjki macicy, stanowiły kobiety w wieku 51-60 lat ( $\mathrm{n}=9,40,53 \%)$, mężatki ( $\mathrm{n}=38,39,30 \%$ ), zamieszkujące miasto powiatowe $(n=33,39,36 \%)$ oraz bezrobotne $(n=11,50,00 \%)$.

Stwierdzono istotną statystycznie zależność pomiędzy wiedzą badanych kobiet na temat dużej liczby partnerek seksualnych obecnego partnera seksualnego jako czynnika zwiększającego ryzyko powstania raka szyjki macicy a formą aktywności zawodowej $(p=0,02)$. Nie stwierdzono natomiast statystycznie istotnej zależności pomiędzy wiedzą badanych kobiet na temat dużej liczby partnerek seksualnych obecnego partnera seksualnego jako czynnika zwiększającego ryzyko powstania nowotworu szyjki macicy a wiekiem $(p=0,46)$, stanem cywilnym $(p=0,59)$, wykształceniem $(p=0,07)$ i miejscem zamieszkania $(p=0,47)$.

\section{DYSKUSJA}

Styl życia seksualnego ma istotny związek z występowaniem raka szyjki macicy. Ryzyko rozwoju raka szyjki macicy jest znacznie wyższe u kobiet, które rozpoczęły inicjację seksualną przed 16. r.ż., aniżeli u kobiet, które rozpoczęły ją po 20. r.ż. [9, 10, $11,12]$.

Badania przeprowadzone przez Czechowską [13] wykazały, że aż 86,0\% badanych kobiet wiedziało, że wczesny wiek inicjacji seksualnej wpływa na ryzyko wystąpienia raka szyjki macicy. Z kolei badania przeprowadzone przez Iwanowicz-Palus i wsp. [7] na grupie 200 kobiet wykazały, że 66,67\% kobiet, które posiadały dzieci, nie wiedziało, że wcześnie rozpoczęte współżycie seksualne ma wpływ na rozwój nowotworów raka szyjki macicy. Natomiast aż 65,52\% kobiet, które nie posiadały dzieci, stwierdziło, że wczesna inicjacja seksualne nie wpływa na rozwój raka szyjki macicy. Wyniki badań tych autorów wykazały istotną statystycznie zależność pomiędzy wiedzą badanych kobiet na temat wcześnie rozpoczętego współżycia seksualnego a rozwojem raka szyjki macicy w korelacji $\mathrm{z}$ doświadczeniami prokreacyjnymi $(\mathrm{p}<0,02)$. Z kolei Krajewska i wsp. [14] w prezentowanych badaniach własnych na grupie 50 kobiet wykazały, że 54,0\% kobiet uznało, że wczesne rozpoczęcie życia seksualnego ma związek z powstawaniem nowotworu szyjki macicy. Natomiast badania przeprowadzone na grupie 100 kobiet przez Pacewicz i wsp. [4] pozwoliły stwierdzić, że kobiety nie wskazywały wczesnego rozpoczęcia współżycia seksualnego jako czynnika ryzyka raka szyjki macicy. Badania przeprowadzone w grupie 260 kobiet przez Ahmeda i wsp. [15] wykazały, że 58,6\% kobiet wiedziało, że wczesna inicjacja seksualna jest czynnikiem ryzyka raka szyjki macicy, 25,7\% z grupy badanych nie wiedziało, jaki jest związek pomiędzy wczesnym rozpoczęciem współżycia a rozwojem tego nowotworu. Natomiast Kamzol i wsp. [16] dowiedli, że badane kobiety nie posiadały wiedzy w zakresie wpływu wczesnej inicjacji na ryzyko wystąpienia raka szyjki macicy. Na podstawie badań własnych stwierdzono, że 52,0\% kobiet wiedziało, że wczesne rozpoczęcie współżycia seksualnego jest czynnikiem zwiększającym ryzyko rozwoju raka szyjki macicy.

Znaczna liczba partnerów seksualnych sprzyja powstawaniu raka szyjki macicy. Kobiety, które posiadają 10 lub więcej partnerów seksualnych, są 3-krotnie bardziej narażone na wystąpienie tego nowotworu w stosunku do kobiet mających jednego partnera seksualnego [17].

Badania Kędziołki i wsp. [18] przeprowadzone na grupie 277 studentek wykazały, że 52,0\% wiedziało, że częsta zmiana partnerów seksualnych stanowi ryzyko zachorowania na raka szyjki macicy w przyszłości. Czechowska [13] wykazała, że 67,0\% badanych kobiet posiadało wiedzę na temat dużej liczby partnerów seksualnych jako czynnika ryzyka raka szyjki macicy. Z badań przeprowadzonych przez Iwanowicz-Palus i wsp. [7] wynika, że ponad połowa badanych - 57,0\% wykazała się dość dobrą wiedzą na temat związku pomiędzy częstą zmianą partnerów seksualnych a występowaniem raka szyjki macicy. Wykazano, że kobiety posiadające wykształcenie średnie istotnie częściej $(\mathrm{p}<0,01)$ wiedziały, że zmiana partnerów seksualnych jest czynnikiem choroby nowotworowej raka szyjki macicy w przeciwieństwie do kobiet legitymujących się innym rodzajem wykształcenia. Krajewska i wsp. [14] stwierdziły, że dla 54,0\% kobiet duża liczba partnerów seksualnych jest czynnikiem ryzyka raka szyjki macicy, a dla 46,0\% nie jest to czynnik ryzyka tej choroby. U Cichońskiej i wsp. [8] 58,0\% badanych kobiet wiedziało, że częsta zmiana partnerów seksualnych zalicza się do czynników ryzyka raka szyjki macicy. Kuczkowskiej i wsp. [19] 70,2\% polskich kobiet oraz 55,4\% fińskich studentek podało, że duża liczba partnerów seksualnych wpływa na rozwój raka szyjki macicy. Natomiast na podstawie badań Pacewicz i wsp. [4] stwierdzono, że badane kobiety $(64,0 \%)$ zaliczyły częstą zmianę partnerów seksualnych do głównych czynników zwiększających ryzyko raka szyjki macicy. Również z badań przeprowadzonych przez Ahmeda i wsp. [15] wynika, że połowa kobiet (50,6\%) wiedziała, że duża liczba partnerów seksualnych wpływa na rozwój raka szyjki macicy. Z kolei Baran i wsp. [20], badając grupę 108 kobiet, stwierdzili, że tylko 23,0\% posiadało wiedzę odnośnie wpływu zmiany partnerów seksualnych na rozwój raka szyjki macicy. Podobnie wynika z badań Sudenga i wsp. [21] - spośród 388 (100,0\%) kobiet, jedynie 30,0\% stwierdziło, że duża liczba partnerów ma związek z powstawaniem raka szyjki macicy. Badania własne wykazały, że 68,0\% kobiet wiedziało, że duża liczba partnerów seksualnych ma wpływ na ryzyko raka szyjki macicy.

Wpływ czynnika męskiego ma ogromny związek z zachorowalnością na raka szyjki macicy. Żony/partnerki mężczyzn uprzednio żonatych lub odbywających kontakty seksualne z prostytutkami są w grupie podwyższonego ryzyka możliwości powstania tego nowotworu [6]. Z przeprowadzonych badań własnych wynika, że 28,0\% kobiet twierdziło, iż duża liczba partnerek seksualnych obecnego partnera nie wpływa na ryzyko powstania raka szyjki macicy, z kolei 37,0\% nie posiadało wiedzy w tym zakresie. Natomiast jedynie 35,0\% badanych uważało, że duża liczba partnerek seksualnych 
obecnego partnera może predysponować do rozwoju raka szyjki macicy.

\section{WNIOSKI}

1. Kobiety wiedzą, że wczesne rozpoczęcie współżycia seksualnego oraz duża liczba partnerów seksualnych stanowi czynnik ryzyka nowotworu szyjki macicy. Natomiast nie posiadają wiedzy na temat wpływu dużej liczby partnerek seksualnych obecnego partnera na możliwość wystąpienia nowotworu szyjki macicy.

2. Istnieje potrzeba prowadzenia działań edukacyjnych wśród kobiet odnośnie wpływu ryzykownych zachowań seksualnych na możliwości rozwoju raka szyjki macicy.

\section{PIŚMIENNICTWO}

1. Ulman-Włodarz I, Nowosielski K, Romanik M, Pozowski J, Jurek M. Świadomość profilaktyki raka szyjki macicy wśród kobiet zgłaszających się do poradni K. Ginekol Pol 2011;82:22-5.

2. Nowicki A, Borowa I, Maruszak M. Zachowania zdrowotne kobiet w zakresie zapobiegania, wczesnego wykrywania stanów przedrukowych i raka szyjki macicy. Ginekol Pol 2008;79:840-9.

3. Łoś J. Skryning cytologiczny raka szyjki macicy. Ginek Prakt 2006;1:10-3

4. Pacewicz M, Krajewska-Kułak E, Krajewska-Ferishah K. Profilaktyka raka szyjki macicy - poziom wiedzy kobiet i mężczyzn. Med Paliat 2012;4:217-28

5. Krajewska M, Owłasiuk A, Litwiejko A. The state of knowledge and health behaviors connected with cervical cancer prevention of the women in Sejny. Probl Med Rodz 2010;1:20-8.

6. Wróbel B. Seksualność kobiety a rak szyjki macicy. Prz Terapeut 2008;5

7. Iwanowicz-Palus GJ, Adamska-Kuźmicka I, Bień A, Stadnicka G. Wiedza i postawy kobiet wobec profilaktyki raka szyjki macicy. Pielęg XXI w 2010;3-4(32-33):9-16.

8. Cichońska M, Borek M, Krawczyń W, Maciąg D. Wiedza kobiet w zakresie zapobiegania nowotoworom piersi i raka szyjki macicy. In: Zboina B, Doliwa-Klepacka A, Bakalarz-Kowalska B, editors. Nauki medyczne, kultura fizyczna i zdrowie. Acta Scientifica Academiae Ostroviensis. Sectio B 2012;1:5-25.

9. Ball C, Madden JE. Badania przesiewowe w kierunku raka szyjki macicy. Współczesna diagnostyka i protokoły tworzone na zasadach EMB. Med Dypl 2003;12(8):49-56.

10. Branca M, Rossi E, Alderisio M, Migliore G, Morosini PL, Vecchione A, et al. Performance of cytology and colposcopy in diagnosis of cervical intraepithelial neoplasia (CIN) in HIV - positive and HIV - negative women. Cytopathology 2001;12:84-93.

11. Gerber J. Profilaktyka onkologiczna na co dzień w ginekologii. Pol Med Rodz 2000;2(2):135-8.

12. Louie KS, Sanjose S, Diaz M, Castellsague' X, Herrero R, Meijer CJ, et al. Early age at first sexyal intercourse and early pregnancy are risk factors for cervical cancer in developing countries. Br J Cancer 2009;100:1191-7.

13. Czechowska K. Wiedza i zachowania prozdrowotne kobiet w zakresie profilaktyki raka szyjki macicy na podstawie badań pacjentek z powiatu jeleniogórskiego. In: Pękała R, editor. Wiedza i doświadczenie pielęgniarki a jej działania promocyjno-edukacyjne. Wyższa Szkoła LDZ w Legnicy. Acta Scholie Superioris Medicinae Legnicensis 2008;1:5-12.

14. Krajewska M, Owłasiuk A, Litwiejko A. The state of knowledge and health behaviors connected with cervical kancer prevention of the women in Sejny. Prob Med Rodz 2010;1(30):20-8.

15. Ahmed SA, Sabitu K, Hadejia I, Achmed R. Knowledge, attitude and practice of cervical cancer among market women in Zaria, Nigeria. Niger Med J 2013;54(5):316-9.

16. Kamzol W, Jaglarz K, Tomaszewski KA, Puskulluoglu M, Krzemieniecki K. Assessment of knowledge abort cervical cancer and its prevention among female students aged 17-26 years. Eur J Obstet Gynecol Reprod Biol 2013 Feb;166(2):196-203. doi: 10.1016/j.ejogrb.2012.10.019. Epub 2012 Nov 7.

17. Kozakiewicz B. Nowotwory złośliwe narządu rodnego. Nowa Med 2003;3(122):117-20.

18. Kędziołka J, Barnaś E, Domka E, Grzegorczyk J, Bojar I. The level of knowledge presented by students from universisties of Rzeszow regarding cervival cancer threat and its risk factors. In: Wdowiak L, Kruk W, Binkowksa-Bury M, editors. Public health and research. Lublin: Wyd. Neurocentrum;2009. p. 183-93.

19. Kuczkowska K, Jankowiak-Siuda K, Wronkowski Z. Knowledge abort cervical cancer among Polish and Finnish female students. Eur J Obstet Gynecol Reprod Biol 2011;156:212-6.

20. Baran W, Kornacka K, Szela S. Ocena wiedzy kobiet z Podkarpacia na temat profilaktyki raka szyjki macicy. Przegląd Medyczny Uniwersytetu Rzeszowskiego i Narodowego Instytutu Leków w Warszawie 2013;3:311-8.

21. Sudenga SL, Rositch AF, Otieno WA, Smith JS. Brief report: knowledge, attitudes, practices and perceived risk of cervical cancer among Kenyan women. Int J Gynecol Cancer 2013;23(5):895-9. 